\title{
The Effects of Cost-Share Participant Experience on Forest Buffer Retention
}

\author{
Katie E. Commender, et al. [full author details at the end of the article]
}

Accepted: 7 February 2020 / Published online: 19 March 2020

(c) Steve Harrison, John Herbohn 2020

\begin{abstract}
Forest conservation buffers provide ecosystem services such as soil and water conservation, wildlife habitat, and clean air. This research studied the experiences and intentions of participants in forest buffer contract programs in Virginia, USA provided by governmental conservation agencies. These programs offer technical assistance and share costs of establishment and maintenance for a period of time typically between 2 and 15 years. Program participant reflections about their experience and intention to retain their forest buffer after their cost-share contract ends were measured. Two-hundred and fifty-one program participants received a mail survey and 136 were returned (response rate $=54 \%$ ). Two-step cluster analysis grouped respondents into four participant types based on responses to questions about buffer maintenance and costs, and perceived environmental benefits. Discontented and Doubtful respondents (23.4\%) experienced financial and maintenance challenges. They also were doubtful about environmental benefits. Contented and Confident respondents $(28.2 \%)$ experienced minimal financial and maintenance difficulties, and were confident that their buffers provide environmental benefits. Benefited with Burden respondents $(22.6 \%)$ also were confident about environmental benefits, but experienced burdensome maintenance and costs. Skeptical without Strife respondents $(25.8 \%)$ were not convinced their buffers provide environmental benefits, but have not had problems with maintenance or costs. A Kruskal-Wallis non-parametric test $(\alpha=0.05)$ indicated that Discontented and Doubtful respondents are least likely to retain their buffer after their cost-share contract expires (rank sum =42.2) and Contented and Confident are most likely (rank sum=82.8). Benefited with Burden and Skeptical without Strife respondents (rank sum $=59.7$ and $=59.8$, respectively) were statistically similar to their Discontented and Doubtful counterparts, but slightly more likely to keep their buffer after their contract expires. Overall, Discontented and Doubtful and Benefited with Burden respondents had larger parcels of land and represented the largest percentage of full-time farmers, whereas Contented and Confident and Skeptical without Strife respondents had smaller parcels and were most likely to be part-time farmers or female. Findings suggest distinctions between types are clear along the onus of management, not necessarily perspectives on conservation. The two most influential drivers of program participation were cost-share
\end{abstract}


assistance and water quality, whereas their most important management objective was improving land health.

Keywords Conservation buffers · Cost-share - Buffer retention · Riparian buffers · Social marketing

\section{Introduction}

Vegetative conservation buffers are strips of trees, shrubs, or grasses that reduce soil erosion, protect water quality and quantity, increase wildlife habitat, improve air quality, and achieve other environmental goals (Lowell and Sullivan 2006). Conservation buffers address specific environmental concerns. For example, wildlife buffers consist of continuous vegetated strips that provide habitat, food, and corridors for wildlife passage (Bentrup 2008). Woody or grass buffers planted on upland contours minimize upslope non-point source pollutant runoff and soil loss (Udawatta et al. 2010). Riparian forest buffers are trees and woody vegetation planted in streamside zones between upland and aquatic habitats that moderate stream bank erosion, improve habitat for aquatic organisms, and reduce non-point source pollution (Weller et al. 2011).

State and federal conservation agencies in the USA provide cost-share funds to offset the expenses of buffer establishment and, in most cases, a 2-to-15 year contract for cost-share and technical assistance is signed. Programs like the Conservation Reserve Program (CRP) and the Conservation Reserve Enhancement Program (CREP) of the United States Department of Agriculture (USDA) Farm Service Agency (FSA) provide yearly rental and maintenance payments to enrollees (USDA 2017), and thousands of farms with millions of acres participate (USDA 2012). Forest buffers are one of the most commonly used conservation practices, particularly in the eastern half of the country (Steven and Lowrance 2011).

Despite cost-share programs and other incentives, overall conservation program participation in the USA remains low (Skelton et al. 2005; Kenwick et al. 2009). When it comes to forest buffers, some argue enrollment is low because they prevent production on arable land (Robles-Diaz-de-Leon 1998; Robles-Diaz-de-Leon and Nava-Tudela 1998). Even when adopted, the condition and permanence of forest buffers is largely unknown because sponsoring agencies lack funding to comprehensively monitor maintenance and retention (Kleiman et al. 2000). Many forest buffer contracts in the USA are approaching end dates and agencies such as the FSA are focusing on program re-enrollment and permanence. Cost-share program participant perspectives and experiences, and their intentions to retain forest buffers are critical given the loss of natural riparian forest areas in the eastern USA, as well as concerns about water quality and quantity (Allen et al. 2001).

The goals of this research were to develop a typology based on the experiences of forest buffer cost-share program participants and use the resulting framework to study buffer retention and participant characteristics. Participant types were determined using responses to survey questions about perceived buffer efficacy and 
management challenges. Land management objectives, reasons for enrolling, and intentions to retain buffers also were measured and compared among participant types. Objectives were to: (1) characterize the experiences, observations, and beliefs among forest buffer cost-share participants; and (2) explore whether and why these variables relate to their management objectives, program participation, and likelihood they will retain their forest buffer after their contract expires. Results point to factors that affect experiences and behavior among forest buffer cost-share participants, highlight needs and opportunities for enhancing program success, and underline implications for incentive programs more broadly in the USA and beyond.

\section{Forest Buffer Adoption}

Socioeconomic traits, such as age (Strong and Jacobson 2005; Valdivia and Poulos 2009), education (Hagan 1996; Arbuckle et al. 2009), occupation (Buttel et al. 1981; Schrader 1995) and economic attributes (Featherstone and Goodwin 1993; Raedeke et al. 2003) are known to influence buffer adoption. Hagan (1996) and Valdivia and Poulos (2009) found that younger landowners often are more interested in buffers, though age played a limited role in a recent study of adoption in Virginia (Trozzo et al. 2014a). Similarly, the relationship between education and interest in buffers may be positive (Hagan 1996) or neutral (Armstrong and Stedman 2012).

Property size also can impact buffer adoption (e.g., Strong and Jacobson 2005; Barbieri and Valdivia 2010; Trozzo et al. 2014a), and there is some evidence that adoption is greatest on large, high-income farms (Napier et al. 2000) perhaps due to program priorities and technical compatibility (Trozzo et al. 2014a). However, Armstrong and Stedman (2012) found that the way land is used rather than parcel size is a better predictor. Indeed, farming status alone may play a more important role, as landowners who do not farm often are more interested in forest buffers (e.g., Arbuckle et al. 2009; Trozzo et al. 2014a, b), but some studies report that smallscale, part-time farmers also are inclined to adopt (Primdahl 1999; Ryan et al. 2003; Trozzo et al. 2014a).

Expected consequences and benefits of forest buffers also are important. Concerns regarding buffer size, maintenance requirements, and land aesthetics can impede adoption (Armstrong and Stedman 2012). Farmers often find forest buffers on stream banks to be messy and aesthetically unappealing (Ryan 1998), and sometimes even remove them because of this (Carr and Tait 1991). Conversely, expected benefits, such as increased crop yield and environmental advantages, can positively affect forest buffer adoption (Valdivia and Poulos 2009; Trozzo et al. 2014a, b).

Extrinsic motivations like cost-share payments are not always associated with forest buffer adoption (Ryan et al. 2003). On the other hand, those with strong intrinsic motivations such as land preservation for future generations generally are more likely to implement forest buffers (Matthews et al. 1993; Valdivia and Poulos 2009), as are those who value environmental conservation (Strong and Jacobson 2005; Arbuckle et al. 2009) and recreation (Arbuckle et al. 2009; Barbieri and Valdivia 2010). Not surprisingly, positive experiences and outcomes among cost-share participants increases satisfaction and retention (Forshay et al. 2005; Wigginton 2009; Knipps 2011). For some 
cost-share participants, CRP buffers are viewed as a source of key ecosystem services such as soil conservation and wildlife habitat, while others view their CRP buffer as a cluster of useless vegetation they are prone to remove (Vandever et al. 2002).

Implementation of conservation practices is not solely a product of landowner objectives (Munsell et al. 2006; VanBrakle et al. 2013). Brinckman and Munsell (2012), for example, observed that biophysical characteristics are significant determinants of landowner experiences, perspectives, and behavior. In general though, most conservation adoption studies focus on the psychosocial factors affecting potential decisions. In that regard, Farmer et al. (2016) and Munsell et al. (2018) point out that post-adoption research generally is lacking.

Liu et al. (2018) conducted a comprehensive literature review of research on farmer best management practices adoption in developed and developing countries. The authors emphasize the importance of scale, need for targeted and tailored communication, and the relevance of anticipated impacts on farm profit. They also underscored the significance of social media and market share through branding and certification. Research on participation in conservation programs, such as CRP and CREP, generally aligns with Liu et al. (2018) and points to gender, attitudes, and experience as key predictors of farmer interest and enrollment (e.g., Pfrimmer et al. 2017; Boyer et al. 2018), but Armstrong et al. (2011) found that contextual factors like politics and property value ultimately are more important when it comes to adoption of cost-share conservation practices.

Many thousands of farmers participate in cost-share conservation programs in North America, and the use of conservation practices the world over has grown $69 \%$ since 2008 (Kassam et al. 2019). With respect to future worldwide adoption, the rates and reasons for use are evolving and environmental challenges such as climate change and population growth are increasingly important in application and design (Kassam et al. 2014). An important question is whether and why these systems will be retained once they are adopted.

Not all technical support programs are specific to governmental agencies, and some non-governmental stakeholder organizations support conservation practices adoption and maintenance programs. In fact, this may be more common outside of North America. However, formal programs involving contracts with governmental agencies and organizations have driven adoption on the continent, and respondents in this study are active participants in such programs. Their perspectives and experiences offer unique insights into the factors affecting forest buffer retention.

\section{Materials and Methods}

Two-hundred and sixty-seven Virginia landowners and land managers who have a current CRP or CREP forest buffer contract were surveyed about perceived project efficacy and management activities. Names and contact information were provided by the Virginia FSA following a Freedom of Information Act request. The study population had 10-15 year cost-share contracts that require they plant open land with approved woody perennial species, have owned or operated their land for at least one year prior to enrolling, and that this land has been classified as agricultural 
commodity cropland for four of the six previous years or marginal pastureland (USDA 2017).

A program participant survey was developed based on conservation adoption literature. Anecdotal interviews with key informants from the USDA Natural Resource Conservation Service, Virginia FSA, Virginia Department of Forestry, and Virginia Soil and Water Conservation Districts also were used. In particular, socioeconomic and demographic themes, along with farming scale and experience, expected buffer benefits and management challenges, and extrinsic and intrinsic motivations were measured. Cognitive interviews with six participants who manage forest buffers were conducted to pretest the survey (after Beatty and Willis 2007). Results were used to refine the instrument by gauging the suitability and reliability of individual questions and construct measurements (after Willis 1999). Once revised, an expert panel reviewed the survey and final modifications were made based on their recommendations.

Survey administration followed Dillman's Tailored Design Method (Dillman et al. 2009). A pre-notification letter summarized the study and notified participants that a paper survey would arrive by mail. One week later, a cover letter and survey were mailed, along with a pre-paid business reply envelope. A reminder postcard was mailed ten days afterward, followed by a cover letter and replacement survey 3 weeks later.

Based on findings and existing literature, respondents were asked to report parcel size in acres (converted to hectares $=$ ha), land tenure, age, gender, education, and income, and whether they are a farmer $(>\$ 1000$ USD in annual product sales following the USDA Economic Research Service definition) and if so, whether they farm full- (30 or more hours per week) or part-time ( $<30$ hours per week). To study variables related to satisfaction and retention, Likert-type survey items were developed to measure the following: (1) the likelihood a respondent will retain their forest buffer after contract termination; (2) the extent to which they believe their forest buffer positively impacts the environment; (3) the level of financial difficulty encountered while maintaining their forest buffer; and (4) how challenging it has been for them to manage their forest buffer.

A single item was used to measure each variable. Likert-type scales were unipolar and consisted of five response points, ranging from $1=$ "not at all" to $5=$ "extremely". The survey also asked respondents to choose their top three management objectives and top three reasons for enrolling in a forest buffer cost-share program from a list of options equally balanced in number across monetary and nonmonetary objectives, and programmatic and non-programmatic reasons (Table 1). Likert-type measurements of each item were treated as single-response ordinal data.

Management objectives were nominal and divided equally between monetary (e.g., "increasing my income") and non-monetary (e.g., "enhancing beauty and scenery") options (after Trozzo et al. 2014a). Respondents who selected two or more monetary objectives were categorized as financially-oriented. They were amenity-oriented if two or more non-monetary objectives were selected. Similarly, a respondent who checked two or more programmatic factors (e.g., "receiving cost-share") were considered programmatic versus non-programmatic (e.g., "improving water quality") enrollees, and vice versa. 
Because late respondents more closely resemble non-respondents (Dillman et al. 2009), non-response bias was evaluated by testing for differences in the responses (e.g., likelihood they will retain their forest buffer after their contract expires) between early and late respondents (after Groves et al. 2002). Late respondents completed and returned a survey following the replacement mailing. T-tests were used to identify statistically significant differences between early and late respondents.

The following variables were used in a two-step cluster analysis to group respondents into types (Tkaczynski 2017): (1) the extent to which they believe their forest buffer positively impacts the environment; (2) the level of financial difficulty encountered while maintaining their forest buffer; and (3) how challenging it has been for them to manage their forest buffer. These variables have been shown in the literature to influence adoption and affect retention, and were also most commonly referenced by agency personnel interviewed during survey development. Experiences and perspectives were compared to management goals and intentions to retain buffers beyond cost-share contracts to study if and how they relate.

The two-step procedure was conducted using IBM ${ }^{\circledR}$ SPSS version 25.0 and chosen for its ability to process categorical and/or continuous data and automatically determine an optimal number of clusters. In other words, all types of data (e.g., nominal, interval) are permissible. In default mode, the test not the researcher determines the optimal number of clusters. The researcher can override the default optimization and select a preferred number of clusters, but this was not done in the case of this study. The strength of two-step cluster results are determined based on a silhouette measure of cohesion and separation, ranging from 0.0 to $1.0(>0.5=$ good). A silhouette score indicates the extent to which

Table 1 Land management objectives and conservation buffer adoption factors reported in binary categories (monetary and non-monetary; programmatic and non-programmatic)

\begin{tabular}{ll}
\hline Monetary & Non-monetary \\
\hline $\begin{array}{l}\text { Land management objectives } \\
\text { Increasing my income }\end{array}$ & $\begin{array}{l}\text { Improving my land's health } \\
\text { Passing my land onto heirs }\end{array}$ \\
Producing agricultural goods & Enhancing beauty and scenery \\
Increasing my land's value & Improving wildlife habitat \\
Improving my land's productivity & Non-programmatic \\
\hline Programmatic & \\
\hline Conservation buffer adoption factors & \\
Receiving cost-share assistance & Improving water quality \\
Increasing CRP/CREP application score & Enhancing wildlife habitat \\
Obtaining yearly rental payments & Conserving soil \\
\hline
\end{tabular}

Participants in a forest buffer cost-share program in Virginia, USA selected the top 3 most important from each list presented in a survey. Choices of 2 or more in in either category were used to group respondents into monetary or non-monetary and programmatic and non-programmatic clusters 
respondents in each cluster are statistically similar and likewise statistically different from other clusters.

Each cluster in the two-step analysis was assigned a descriptive title that reflects differences across the three clustering variables. Socioeconomics, demographics, and land ownership and use characteristics were compared across respondent types and a Kruskal-Wallis non-parametric procedure (Kruskal and Wallis 1952) was used to test for significant differences in terms of intention to retain forest buffers. Management objectives, reasons for enrolling in a cost-share buffer program, and demographics and property characteristics were compared between respondent types using percentages and other descriptive results.

\section{Results}

Two-hundred and fifty-one surveys were successfully delivered and 136 were completed and returned for a 54.2\% adjusted response rate. No significant differences were observed between early and late respondents in terms of the four Likert-type items used to measure long-term buffer retention, management challenges, financial strain, and environmental impact. Two-step cluster analysis resulted in four relatively evenly distributed participant types based on a good silhouette measure of cohesion and separation ( 0.7 out of 1$)$. Means for the three variables in the two-step cluster analysis were used to assign a descriptive title for each cluster which formed the program participant typology (Table 2)-Discontented and Doubtful (23.4\%), Benefited with Burden (22.6\%), Skeptical without Strife (25.8\%), and Contented and Confident (28.2\%).

Experience and intention to retain forest buffers differed significantly among participant types $(\alpha=0.05)$ (Table 2$)$. Pairwise comparison using inter-variable separation of rank-sum scores in a Kruskal-Wallis test indicated that the largest differences between clusters were observed in terms of environmental benefits, followed by maintenance burdens. Discontented and Doubtful respondents were least likely to have had positive experiences and reported being least likely to retain their buffer after contract expiration. Contented and Confident respondents reported little in the way of negative experiences and were most likely to retain their buffer. Both Benefited with Burden and Skeptical without Strife respondents were similar to Discontented and Doubtful respondents when it comes to keeping their buffer after their contract expires, but experiences and perceptions differed with the former being burdened in buffer maintenance and the latter questioning the environmental benefits without being inconvenienced.

Discontented and Doubtful respondents reported significantly higher levels of financial strain compared to other respondent groups (Table 2). They also reported significantly greater maintenance difficulties compared to Contented and Confident and Skeptical without Strife respondents. Discontented and Doubtful also were significantly more doubtful about whether their buffers positively impact environmental health compared to Benefited with Burden and Contented and Confident respondents. 
Table 2 Statistical comparisons of responses to survey questions about the benefits and challenges (items) of forest buffers among cost-share program participant types in Virginia, USA

\begin{tabular}{|c|c|c|c|c|c|}
\hline Items & $\begin{array}{l}\text { Discontented } \\
\text { and doubtful } \\
(\mathrm{n}=29) \\
\text { Rank sum } \\
\text { (mean 1-5) }\end{array}$ & $\begin{array}{l}\text { Benefited with } \\
\text { burden }(\mathrm{n}=28) \\
\text { Rank sum } \\
\text { (mean } 1-5)\end{array}$ & $\begin{array}{l}\text { Contented } \\
\text { and confident } \\
(\mathrm{n}=35) \\
\text { Rank sum } \\
\text { (mean } 1-5)\end{array}$ & $\begin{array}{l}\text { Skeptical } \\
\text { without strife } \\
(\mathrm{n}=32) \\
\text { Rank sum } \\
\text { (mean } 1-5)\end{array}$ & $\chi^{2} ; d f ; p$ \\
\hline $\begin{array}{l}\text { Environmental } \\
\text { benefits }\end{array}$ & $42.6^{\mathrm{a}}(2.9)$ & $70.1^{\mathrm{b}}(3.7)$ & $95.4^{\mathrm{c}}(4.2)$ & $38.0^{\mathrm{a}}(3.0)$ & $62.9 ; 3 ; 0.00 *$ \\
\hline $\begin{array}{r}\text { Maintenance } \\
\text { challenges }^{\wedge}\end{array}$ & $34.6^{\mathrm{a}}(2.8)$ & $33.0^{\mathrm{a}}(3.0)$ & $91.0^{\mathrm{b}}(4.5)$ & $82.4^{\mathrm{b}}(4.3)$ & $74.2 ; 3 ; 0.00 *$ \\
\hline Financial strain^^ & $33.8^{\mathrm{a}}(3.5)$ & $63.4^{\mathrm{b}}(4.5)$ & $78.9^{\mathrm{b}}(4.8)$ & $69.8^{\mathrm{b}}(4.7)$ & $35.0 ; 3 ; 0.00 *$ \\
\hline $\begin{array}{l}\text { Intentions to } \\
\text { retain }\end{array}$ & $42.2^{\mathrm{a}}(3.1)$ & $59.7^{\mathrm{a}}(3.8)$ & $82.8^{\mathrm{b}}(4.4)$ & $59.8^{\mathrm{a}}(3.8)$ & $24.7 ; 3 ; 0.00 *$ \\
\hline
\end{tabular}

The four items measured experiences across four participant types (Discontented and Doubtful; Benefited with Burden; Contented and Confident; Skeptical without Strife). Rank sum scores and means are presented

Rank sums followed by the same letter are not significantly different according to pairwise comparisons. Two-step cluster analysis silhouette measure of cohesion and separation $=0.7$; predictor importance order $=$ maintenance effort; land health impact; financial impact

*Significance $(\alpha=0.05)$

$\wedge$ Lower rank sum indicates greater challenge and strain

Benefited with Burden respondents were significantly more likely to believe in positive environmental outcomes compared to Discontented and Doubtful and Skeptical without Strife respondents, but also significantly more likely to report burdensome maintenance compared to Contented and Confident and Skeptical without Strife respondents (Table 2). Skeptical without Strife respondents were significantly more doubtful about the environmental benefits than were Benefited with Burden and Contented and Confident respondents, but did not differ in terms of their struggle to maintain their buffer when compared to Contented and Confident respondents. They also reported experiences similar to Benefited with Burden and Contented and Confident respondents in terms of financial challenges.

Most respondents across program participant types were 45 years old or older, and male (Table 3). More than half had college degrees at the Bachelors or Graduate level and most commonly earned between $\$ 50,000$ to \$150,000 USD annually. The vast majority of respondents were farmers, of which just over half worked parttime. The average parcel size across respondent types ranged from 72 (Skeptical without Strife) to 162 ha (Discontented and Doubtful) (converted from acres; range 0.5-2023 ha; SE=45). Years that they have owned land spanned from 23 (Contented and Confident) to 31 years (Skeptical without Strife) (range 1-79; SE =1.6).

Age varied across participant types, with the largest noticeable difference being between Skeptical without Strife (nearly 60\% over 65 and none 25-44) and Discontented and Doubtful (over half 45-64). These same two groups most often made between $\$ 50,000$ and $\$ 150,000$ USD per year compared to their counterparts. Contented and Confident included the largest percentage of female respondents 


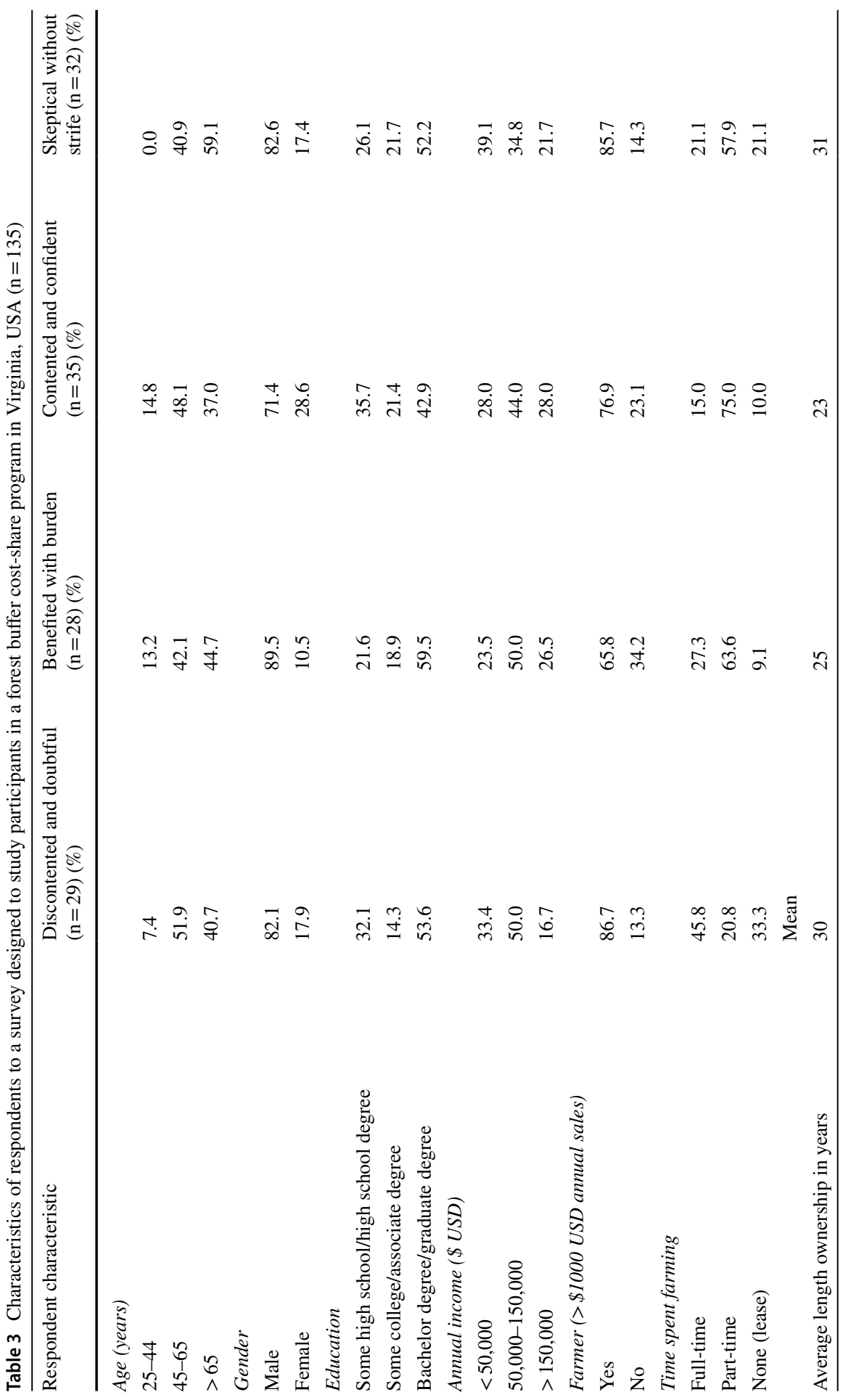




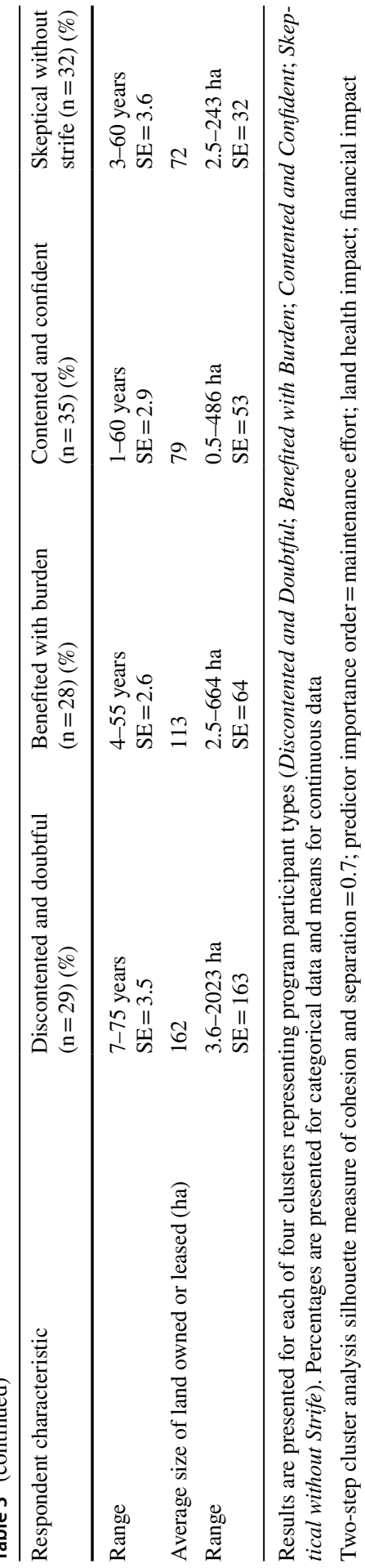


(nearly 29\%) and Benefited with Burden had the largest percentage of respondents with bachelors and graduate degrees, but also the fewest that sold more than $\$ 1000$ USD of products per year. Close to half (46\%) of Discontented and Doubtful farmers were full-time and on average they owned or leased the largest parcels of land (mean = 162 ha; $\mathrm{SE}=163$ ).

Land management objectives and factors influencing conservation buffer program participation varied across respondent type (Figs. 1, 2). Improving land health was the most frequently reported management objective, while the other top two objectives diverged. Similarities in land management objectives reported between respondent types was most prominent with regard to increasing income (range 28-38\%). The greatest separation occurred with respect to increasing land value (range 0-50\%). Discontented and Doubtful respondents were the only type that regularly reported monetary aims.

Within types, Discontented and Doubtful respondents most commonly reported that improving land health, value, and productivity were most important when deciding to participate in a forest buffer cost-share program. Benefited with Burden respondents most often favored enhancing land health, passing land onto heirs, and enhancing wildlife habitat. Skeptical without Strife respondents reported that improving land health, enhancing wildlife habitat, and increasing land value were primary management objectives. Lastly, Contented and Confident respondents were interested in improving land health, followed by enhancing wildlife habitat as well as beauty and scenery.

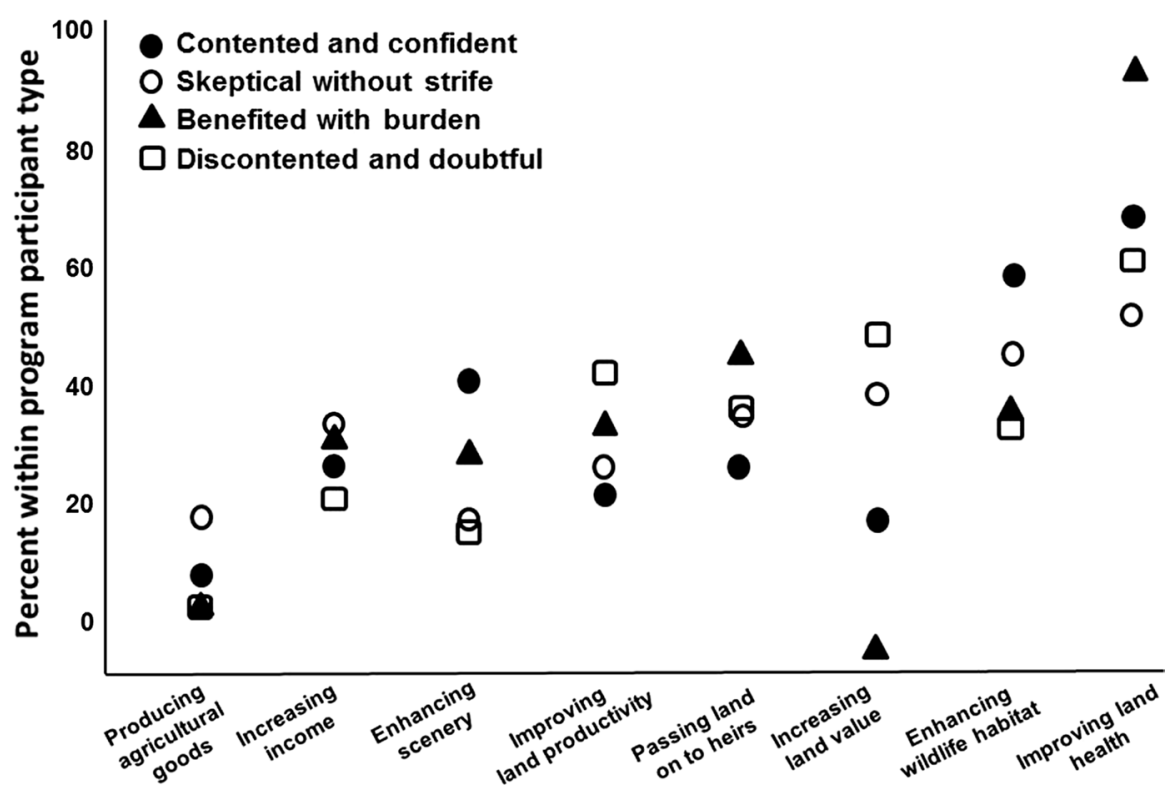

Fig. 1 Percent frequency of top 3 land management objectives for forest buffer cost-share program participants in Virginia, USA. Results are reported for four participant types depicting differences in program experience (Discontented and Doubtful; Benefited with Burden; Contented and Confident; Skeptical without Strife) 


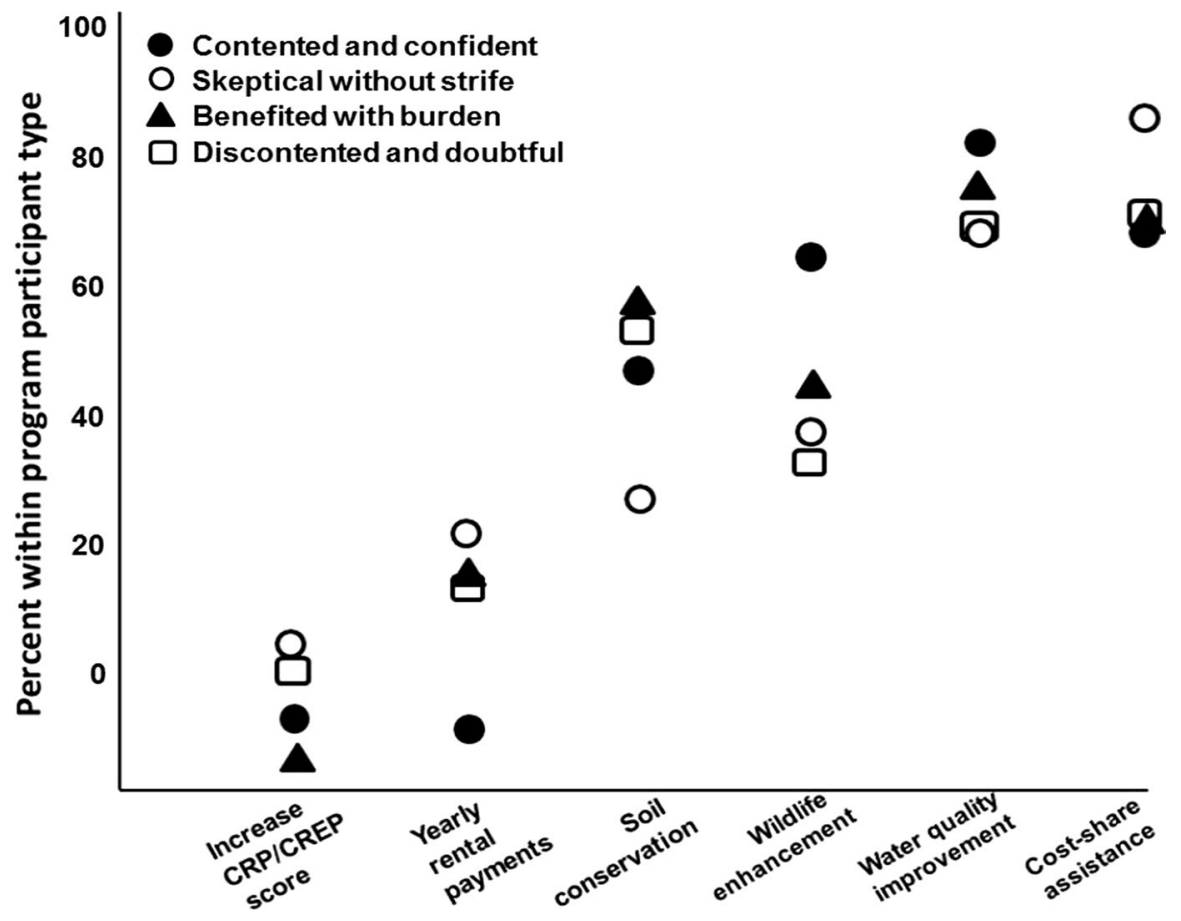

Fig. 2 Percent frequency of top 3 reasons for enrolling in a forest buffer cost-share program in Virginia, USA. Results are reported for four participant types depicting differences in program experience (Discontented and Doubtful; Benefited with Burden; Contented and Confident; Skeptical without Strife)

The two most common factors affecting program enrollment included financial cost-share assistance and water quality improvement. The third most commonly reported factor varied between conserving soil and enhancing wildlife habitat. Similarities in the preferentially selected factors between participant types occurred primarily in terms of improving water quality (range 75-83\%), while the largest separation occurred with respect to the importance of yearly rental payments (range 6-31\%).

Notwithstanding the prevalence of financial cost-share assistance, all participant types generally selected non-programmatic adoption factors. Discontented and Doubtful and Benefited with Burden respondents most commonly reported financial cost-share assistance, improving water quality, and conserving soil. Contented and Confident and Skeptical without Strife respondents most commonly reported financial cost-share assistance, improving water quality, and enhancing wildlife habitat. 


\section{Discussion}

Distribution across all forest buffer program participant types was fairly even, with the fewest number of respondents in the Benefited with Burden (22.6\%) type, followed by Discontented and Doubtful (23.4\%). The largest number of respondents were Contented and Confident (28.2\%), which was trailed by Skeptical without Strife (25.8\%). This means that over half of the study respondents did not feel they had been significantly burdened by maintenance or financial requirements. The implications are important as strain and skepticism are not independently sufficient for speaking about trends in buffer retention. The existence of one or the other for a program participant only alters the emphasis on what is needed to improve the likelihood they will retain their forest buffer.

Contented and Confident respondents included the highest percentage of respondents between 25 and 44 years of age. This respondent group also included the highest percentage of females, part-time farmers, and highest income earners. Their parcels also were on average the smallest and owned for the least amount of time. Disconnected and Doubtful respondents did not include the highest rates of older or male respondents, but on average they owned the largest tracts of land for the longest amount of time. The percentage of farmers among these program participants was the highest across all four types, and rates of full-time farming far exceeded the others. These trends suggest that moderate income earning farmers with large tracts of land are more likely to question the efficacy of their forest buffer and most often struggle to maintain it. On the other hand, newer and younger owners who farm less, own smaller parcels, and generally make the most did not question efficacy nor struggle as much.

Points of distinction between Benefited with Burden and Skeptical without Strife respondents included income and farming. Benefited with Burden respondents had the overall highest percentage of respondents earning \$50,000 USD or more per year, and the overall lowest percentage of farmers. Conversely, Skeptical without Strife respondents had the overall largest percentage earning less than $\$ 50,000$ USD per year and were only one percentage point lower than Discontented and Doubtful respondents in terms of the percentage of farmers. When uncertain but not hindered, cost-share program participants are likely to be farmers of smaller parcels and have the means to manage their forest buffer. On the other hand, participants that perceive environmental benefits may be more likely to earn more and have advanced education, but also less likely to farm and therefore may struggle with management.

Contented and Confident respondents were most likely to perceive that their buffers provided environmental benefits and reported minimal financial burden and maintenance challenges. Not surprisingly, they also were most likely to state that they intend to retain their forest buffer. This aligns with earlier studies where overall contentment correlates with satisfaction related to environmental benefits (e.g., Vandever et al. 2002; Forshay et al. 2005; Rossi et al. 2010). Another potential driver of satisfaction is the emphasis on non-monetary land management objectives, including "improving land health", "expanding wildlife habitat", and 
"enhancing beauty and scenery". For example, participants in Mississippi who met their non-monetary goals were also more likely to be satisfied with their costshare program (Wigginton 2009).

Contented and Confident respondents also reported that non-programmatic factors, such as "improving water quality" and "enhancing wildlife habitat", were most influential in their decision to enroll in a forest buffer cost-share program, suggesting that their interest in conservation is a product of strong intrinsic motivations and environmental goals. By contrast, Discontented and Doubtful respondents were the only type that chose monetary land management objectives, such as "increasing land value", more often than non-monetary goals. They also were unsure about environmental benefits and reported substantial financial burden and management difficulties, which is not surprising given the greatest rates of dissatisfaction in previous studies are associated with substantial maintenance challenges (Vandever et al. 2002) and impediments to enhancing land value (Rilla et al. 2000).

Also not surprising was that Discontented and Doubtful respondents were much less likely to report that they intend to keep their forest buffer. Results from previous studies suggest that landowners are less likely to adopt conservation practices if they prioritize monetary land management objectives (Ryan et al. 2003; Forshay et al. 2005; Arbuckle et al. 2009; Rossi et al. 2010), which likely relates to farming on larger parcels in the case of Discontented and Doubtful owners. Findings in this study do not counter this supposition, but indicate that some participants in forest buffer cost-share programs prioritize non-monetary returns, many of whom farm and have large parcels. In light of this, it is worth noting that those with monetary objectives generally adopt conservation practices that match their production goals (Ryan et al. 2003), but Discontented and Doubtful respondents may have found forest buffers potentially complementary though they struggle to see benefits because of financial aims.

Although "financial cost-share assistance" was highly influential in their decision to participate in a cost-share program, "improving water quality" was equally important for Discontented and Doubtful respondents and "conserving soil" not far behind. This differs from previous studies where extrinsic motivations, like costshare payments, had little to no influence on program participation (e.g., Ryan et al. 2003). At the same time, findings generally support the notion that intrinsic motivations and amenity values play an important role in landowner interests (Strong and Jacobson 2005; Arbuckle et al. 2009; Valdivia and Poulos 2009).

Between Contented and Confident and Discontented and Doubtful respondent types, fall Benefited with Burden and Skeptical without Strife. Benefited with Burden respondents reported that they believe their forest buffers positively impact the environment, but this service comes with substantial maintenance challenges. This reflects findings in Vandever et al. (2002), where satisfaction declined when maintenance demands were high but appreciation for environmental benefits remained steady. Nonetheless, the likelihood of buffer retention did not differ significantly between Benefited with Burden and Discontented and Doubtful respondents.

Benefited with Burden respondents also reported that non-monetary land management objectives, including "improving land health" and "passing land on to heirs", were most influential in their decision to enroll in a forest buffer cost-share program. 
They perceived monetary objectives, such as "increasing land value," to be far less important. According to Wigginton (2009), satisfied cost-share program participants often have non-monetary goals, which appear to have been unable to overcome the effects of extensive maintenance on retention in the case of Benefited with Burden respondents.

Preferences driving program participation among Benefited with Burden respondents were similar to those in the Contented and Confident group. Although "financial cost-share assistance" commonly influenced their decision, non-programmatic factors such as "improving water quality" were ranked highest, whereas "conserving soil" trailed closely behind. Results complement studies in which intrinsic motivations and amenity values are strongly associated with forest buffer adoption (Strong and Jacobson 2005; Arbuckle et al. 2009; Valdivia and Poulos 2009).

While difficulties associated with buffer maintenance and financing were minimal, Skeptical without Strife respondents were doubtful about the environmental benefits of their forest buffer. Vandever et al.'s (2002) survey of CRP program participants found that those who were most satisfied also reported being pleased with the environmental benefits that they perceive are provided by their buffer. Even when forest buffers are easy to maintain and present few financial challenges, some may underperform or seem irrelevant in the eye of the program participant. Thus, it is not surprising that Skeptical without Strife respondents reported being less inclined to retain their buffer. Limited maintenance concerns and financial burdens, however, suggest they are generally satisfied and capable of managing forest buffers, and, therefore, may be more prone to keep theirs if its conservation value increases (Forshay et al. 2005; Rossi et al. 2010).

The most important land management objectives among Skeptical without Strife respondents included "improving land health" and "enhancing wildlife habitat", and the monetary objective "increasing land value". More influential for Skeptical without Strife respondents was the "financial cost-share assistance". However, they were still grouped into the non-programmatic category with "improving water quality" and "enhancing wildlife habitat" closely following in importance. In Missouri, farmers were more likely to adopt conservation practices if they held non-monetary land management objectives (Arbuckle et al. 2009), yet results in this study suggest, as did Ryan et al. (2003), that adopters can hold both monetary and non-monetary objectives, particularly if these objectives meet their land use goals. The important question is whether and why forest buffers are established and maintained to achieve a spectrum of land uses and owner objectives.

Discontented and Doubtful respondents reported being the least likely to retain their forest buffer, though evolving management experiences and participation preferences may change their intentions. For one, buffers designed to add value through specialty crop production could help improve monetary efficiencies and opportunities (Trozzo et al. 2014b). Gains from cropping may be strengthened through measurements and valuation of environmental services, including improving water and soil quality, which were observed to be important among all respondent types.

Since maintenance costs also were a concern, supplementing program benefits with increased yearly maintenance payments or private market incentives and investment could reduce financial strain, particularly for those full-time farmers 
who struggle the most. Emphasis on program accessibility and diverse participation also may increase the number of new and different cost-share enrollees, which could be particularly strategic in light of evolving ownership and land use preferences. Forest buffers also should be installed using best site preparation practices and designed with fast-growing, adaptive, and resilient species that outcompete weeds and pests to reduce maintenance burdens, and provide multifunctional benefits that include timber and non-timber products.

Unlike Discontented and Doubtful respondents, Benefited with Burden respondents observed positive environmental benefits in the midst of struggling to maintain their buffer, which may be enough to improve the likelihood of retention. It also could be that they work hard to ensure their buffer performs, yet struggle to reconcile that with the effort needed to do so. This also may be due to financial means and extrinsic drivers of enrollment. Either way, they were significantly less likely to retain their forest buffers when compared to Contented and Confident respondents, but several changes may improve overall experiences and alter long-term prospects. Non-monetary benefits, such as improving water quality and conserving soil, are important and aiding maintenance efforts for accessing and sustaining these values through technical assistance, specialty equipment, and opportunities like grant programs dedicated to upkeep may positively affect intentions. It also could be that, like Discontented and Doubtful respondents, conditions may improve for Benefited with Burden respondents through the use of specialty species for production and sales, or for personal reasons.

Although Skeptical without Strife respondents did not necessarily struggle with maintenance and financial costs, they still doubted the environmental benefits of their forest buffer. This uncertainty appears to be enough to diminish the overall likelihood they will retain their forest buffer. Perhaps their concern stems from buffer failure due to limited maintenance, which also leads to a sense of negligible labor and financial demand. Regardless, an enhanced sense of certainty regarding non-monetary environmental benefits, including improved land health and enhanced wildlife habitat, would likely reduce skepticism while also aligning these benefits and their land management objectives.

Although Contented and Confident respondents were largely satisfied and highly likely to keep their forest buffer, changes in the maintenance requirements or financial strain could quickly redirect this trend. Preventative assistance in terms of maintenance and financial programs, along with efforts to measure, optimize, and sustain environmental services could create conditions that positively affect their experience. Moreover, strategies to reduce maintenance and financial demands, while enhancing the observability and value of environmental services could change the situation for Benefited with Burden and Skeptical without Strife respondents. If specific improvements for these two types of participants occur and positive outcomes continue among Contented and Confident respondents, the inclination to retain their forest buffer could increase among upwards of $75 \%$ of cost-share participants. Expanding and further diversifying enrollment also would likely transfer any support to a wider array of potential forest buffer cost-share program participants. 


\section{Conclusion}

This study identified four types of forest buffer cost-share program participants. Those who are most likely to retain their forest buffer reported that they had not experienced substantial financial strain or maintenance challenges, and that their buffers provide environmental services. Participant types differed in terms of their perceptions related to the environmental benefits of their buffer and the challenges they face in maintaining them. All types reported that financial assistance and water quality were top reasons for participating in a forest buffer cost-share program. They also all reported that improving land health was their most important management objective.

Study findings advance our understanding of forest buffer adoption and costshare participation by linking landowner motivations and aims to post-adoption experience, and exploring the relationships between landowner experience and demographics, land use, and intentions to keep their forest buffer after their costshare contract expires. While intrinsic and extrinsic motivations appear to influence conservation buffer adoption, intrinsic motivations and amenity values may be more important when it comes to satisfaction and long-term retention. Findings also indicate that conservation buffer programs are more likely to succeed if they reduce financial strain and maintenance challenges, along with improving participation among lower income earners, next generation owners, and women.

In terms of retention, results of this study point to the value in distinguishing between initial motivations leading up to adoption, which tend to balance environmental, financial, and amenity aims, and post-adoption experiences that often are confined to intrinsic needs such as minimizing costs and maintenance. Increasing emphasis on ecosystem services, such as carbon sequestration and water quality, and growth in international institutional support are likely to profoundly affect worldwide adoption, but long-term investments, whether governmental, non-governmental, or private, are necessary to realize and sustain benefits over time. Also critical are issues of access and equity, which were evident in the findings of the study and many others in North America and beyond. Hence, balancing exogenous environmental goals and participant needs, as well as social parity and diversity are key issues for forest buffer retention regardless of which continent, in what context, and with whom one collaborates.

When it comes to reducing the number of burdened adopters, cost-share programs should focus on improving financial opportunities associated with approved buffer systems. This could include an increase in yearly maintenance payments to offset costs and buffer designs that include adaptive and resilient species, which require less upkeep, or agroforestry tree species that produce crops such as fruits and nuts. They also could incorporate private investment and environmental markets. Another possibility relates to tax incentives and the benefits of forest buffers as they correspond to expense claims associated with establishment and maintenance. Said differently, can forest buffer conservation investments be treated like timber investments? In addition, long-term buffer retention among participants in typical fixedlength cost-share programs would likely increase if options were flexible in terms 
of species selection and production, broadly accessible to stakeholders across representative demographics and land use goals, and more easily aligned with diverse environmental outcomes and reasons for enrolling. For permanent programs where removal is not an option, species selection and design parameters are additionally important to increase enrollment, provide positive experiences, and ensure legitimate and committed involvement.

Conservation agencies and stakeholders should balance programs that reduce buffer failure among participants who are satisfied with those that are designed to help improve conditions for participants who are dissatisfied. Strategic possibilities include increasing use of multifunctional buffers that include tree species which provide food and floral production opportunities, and potential for establishing more extensive, less-demanding forest buffers. Additional steps include evaluating participant diversity and program accessibility, and the role that forest buffers play in tax incentives, along with valuation of land relative to future transactions such as resale and balancing annual assets. Long-term conservation gains rely on strategic advances that expand access and embrace varying practitioner perspectives, while also improving their experience.

\section{References}

Allen JA, Keeland BD, Stanturf JA, Clewell AF, Kennedy HE (2001) A guide to bottomland hardwood restoration. Joint publication of the U.S. Department of Interior Geological Survey (Information and Technology Report USGS/BRD/ITR-2000-0011 and U.S. Department of Agriculture Forest Service General Technical Report SRS-40

Arbuckle JG, Valdivia C, Raedeke A, Green J, Rikoon JS (2009) Non-operator landowner interest in agroforestry practices in two Missouri watersheds. Agrofor Syst 75:73-82

Armstrong A, Stedman RC (2012) Landowner willingness to implement riparian buffers in transitioning watersheds. Landsc Urban Plan 105:211-220

Armstrong A, Ling E, Stedman R, Kleinman P (2011) Adoption of the Conservation Reserve Enhancement Program in the New York City watershed: the role of farmer attitudes. J Soil Water Conserv 66:337-344

Barbieri C, Valdivia C (2010) Recreational multifunctionality and its implications for agroforestry diffusion. Agrofor Syst 79:5-18

Beatty PC, Willis GB (2007) The practice of cognitive interviewing. Public Opin Quart 71:287-311

Bentrup G (2008) Conservation buffers: design guidelines for buffers, corridors, and greenways. General Technical Reports SRS-109. Department of Agriculture, Forest Service, Southern Research Station, Asheville

Boyer TA, Tong B, Sanders LD (2018) Soil and water conservation method adoption in a highly erosive watershed: the case of Southwest Oklahoma's Fort Cobb watershed. J Environ Plan Manag 61:1828-1849

Brinckman MD, Munsell JF (2012) Disproportionality, social marketing, and biomass availability: a case study of Virginia and North Carolina family forests. South J Appl For 36:85-91

Buttel FH, Gillespie GW Jr, Larson GW III, Harris CK (1981) The social bases of agrarian environmentalism: a comparative analysis of New York and Michigan farm operators. Rural Soc 46:391-410

Carr S, Tait J (1991) Differences in the attitudes of farmers and conservationists and their implications. J Environ Manag 32:281-294

Dillman DA, Smyth JD, Christian LM (2009) Internet, mail and mixed-model surveys: the tailored design method, 3rd edn. Wiley, Hoboken 
Farmer JR, Ma Z, Drescher M, Knackmuhs E, Dickinson SL (2016) Private landowners, voluntary conservation programs, and implementation of conservation friendly land management practices. Conserv Lett 10:58-66

Featherstone AM, Goodwin BK (1993) Factors influencing a farmer's decision to invest in long-term conservation improvements. Land Econ 69:67-81

Forshay KJ, Morzaria-Luna HN, Hale B, Predick K (2005) Landowner satisfaction with the wetlands reserve program in Wisconsin. Environ Manag 36:248-257

Gold MA, Garrett HE (2009) Agroforestry nomenclature, concepts, and practices. In: Garrett HE (ed) North American agroforestry: an integrated science and practice. American Society of Agronomy, Madison, pp 1-23

Groves RM, Dillman DA, Eltinge JL, Little RJA (2002) Survey nonresponse. Wiley, New York

Hagan PT (1996) Evaluating determinants of participation in voluntary riparian buffer programs: a case study of Maryland's buffer incentive program. Master's thesis. University of Maryland

Kassam A, Derpsch R, Friedrich T (2014) Global achievements in soil and water conservation: the case of conservation agriculture. Int Soil Water Conserv Res 1:5-13

Kassam A, Friedrich T, Derpsch R (2019) Global spread of conservation agriculture. Int J Environ Stud 76:29-51

Kenwick RA, Shammin MR, Sullivan WC (2009) Preferences for riparian buffers. Landsc Urban Plan 91:88-96

Kleiman DG, Reading RP, Miller BJ, Clark TW, Scott JM, Robinson J, Wallace RL, Cabin RJ, Felleman F (2000) Improving the evaluation of conservation programs. Conserv Biol 14:356-365

Knipps ACS (2011) Evaluation of the landowners incentive program in Texas: 1997-2007. Texas A\&M University Dissertation. ProQuest Dissertations Publishing

Kruskal W, Wallis WA (1952) Use of ranks in one-criterion variance analysis. J Am Stat Assoc 47:583-621

Liu T, Bruins RJF, Heberling MT (2018) Factors influencing farmers' adoption of best management practices: a review and synthesis. Sustainability 10:1-26

Lowell ST, Sullivan WC (2006) Environmental benefited of conservation buffers in the United States: evidence, promise, and open questions. Agric Environ Ecosyst 112:240-260

Matthews S, Pease SM, Gordon AM, Williams PA (1993) Landowner perceptions and the adoption of agroforestry practices in southern Ontario, Canada. Agrofor Syst 21:159-168

Munsell JF, Germain RH, Bevilacqua E, Schuster RM (2006) Voluntary best management practice implementation by nonindustrial private forestland owners in New York City's water supply system. N. J. Appl For 23:133-140

Munsell JF, Addlestone BJ, Bukowski CJ, Nkembi L, Kingsly N, Moore EA (2018) Relationships between agroforestry and community development according to practitioners. Agrofor Syst 92:1387-1396

Napier TL, Tucker M, McCarter S (2000) Adoption of conservation production systems in three Midwest watersheds. J Soil Water Conserv 55:123-134

Pattanayak SK, Mercer DE, Sills E, Yang J (2003) Taking stock of agroforestry adoption studies. Agrofor Syst 57:173-186

Pfrimmer J, Gigliotti L, Stafford J, Schumann D, Bertrand K (2017) Motivations for enrollment into the conservation reserve enhancement program in the James River Basin of South Dakota. Hum Dimen Wild 22:382-389

Primdahl J (1999) Agricultural landscapes as places of production and for living in: owner's versus producer's decision making and the implications for planning. Landsc Urban Plan 46:143-150

Raedeke AH, Green JJ, Hodge SS, Valdivia C (2003) Farmers, the practice of farming and the future of agroforestry: an application of Bourdieu's concepts of field and habitus. Rural Soc 68:64-86

Rilla E, Sokolow AD, Kozloff R, Lemp C (2000) California farmers and conservation easements: motivations, experiences, and perceptions in three counties. Research Paper \#4. University of California Agricultural Issues Center, Davis

Robles-Diaz-de-Leon LF (1998) Evaluation of potential gross income from non-timber products in a model riparian forest for the Chesapeake Bay watershed. Agrofor Syst 44:215-225

Robles-Diaz-de-Leon LF, Nava-Tudela A (1998) Playing with Asimina triloba (pawpaw): a species to consider when enhancing riparian forest buffer systems with non-timber products. Ecol Model 12:169-193

Rossi FJ, Carter DR, Alavalapati JRR, Nowak JT (2010) Forest landowner participation in state-administered southern pine beetle cost-share programs. South J Appl For 34:3 
Ryan RL (1998) Local perceptions and values for a Midwestern river corridor. Landsc Urban Plan 42:225-237

Ryan RL, Erickson DL, DeYoung R (2003) Farmers' motivations for adoption conservation practices along riparian zones in a mid-western agricultural watershed. J Environ Plan Manag 46:19-37

Schrader CC (1995) Rural greenway planning: the role of streamland perception in landowner acceptance of land management strategies. Landsc Urban Plan 33:375-390

Skelton P, Josaih SJ, King JW, Brandle JR, Helmers GA, Francis CA (2005) Adoption of riparian forest buffers on private lands in Nebraska, USA. Small Scale For Econ Manage Policy 4:185-204

Steven DD, Lowrance R (2011) Agricultural conservation practices and wetland ecosystem services in the wetland-rich Piedmont-Coastal Plain region. Ecol Appl 21:3-17

Strong NA, Jacobson MG (2005) Assessing agroforestry adoption potential utilizing market segmentation: a case study in Pennsylvania. Small Scale For Econom Manage Policy 4:215-228

Tkaczynski A (2017) Segmentation using two-step cluster analysis. In: Dietrich T, Rundle-Thiele S, Kubacki K (eds) Segmentation in social marketing. Springer, Singapore

Trozzo K, Munsell JF, Chamberlain JL, Aust WM (2014a) Potential adoption of agroforestry riparian buffers based on landowner and streamside characteristics. J Soil Water Qual 69:140-150

Trozzo K, Munsell JF, Chamberlain JL (2014b) Landowner interest in multifunctional agroforestry riparian buffers. Agrofor Syst 8:619-629

Udawatta PU, Garret HE, Kallenbach R (2010) Agroforestry buffers for nonpoint source pollution reductions from agricultural watersheds. J Environ Qual 40:800-806

USDA Economic Research Service (2009) 2007 Census of Agriculture. United States summary and state data, vol 1. Geographic area series. Part 51. AC-07-A-51

USDA Farm Service Agency (2012) Conservation reserve program annual summary and enrollment statistics. https://www.fsa.usda.gov/Assets/USDA-FSA-Public/usdafiles/Conservation/PDF/summa ry12.pdf. Accessed 3 Feb 2020

USDA Farm Service Agency (2015) Perspective participants/general public. https://www.fsa.usda.gov/progr ams-and-services/conservation-programs/prospective-participants/index. Accessed 27 May 2015

USDA Farm Service Agency (2017) Conservation programs. https://www.fsa.usda.gov/programs-and-servi ces/conservation-programs/index. Accessed 28 Mar 2017

Valdivia C, Poulos C (2009) Factors affecting farm operators' interest in incorporating riparian buffers and forest farming practices in northeast and southeast Missouri. Agrofor Syst 75:61-71

VanBrakle JD, Germain RH, Munsell JF, Stehman SV (2013) Do forest management plans increase BMP implementation on family forests? A formative evaluation in New York City's watershed. J For 11:108-114

Vandever MW, Allen AW, Sexton NR (2002) Selected effects of the Conservation Reserve Program on program participants: a report to survey respondents. U.S. Geological Survey, Fort Collins Science Center, CO: Open File Report 02-476

Weller DE, Baker ME, Jordan TE (2011) Effects of riparian buffers on nitrate concentrations in watershed discharge: new models and management implications. Ecol Appl 21:1679-1695

Wigginton CD (2009) Evaluation of cost-share assistance programs as an incentive for wildlife habitat management and conservation on private lands in Mississippi. Mississippi State University, ProQuest Dissertations Publishing, Mississippi State

Willis GB (1999) Cognitive interviewing: a "how to" guide. https:/www.hkr.se/pagefiles/35002/gordo nwillis. Accessed 17 June 2015

Publisher's Note Springer Nature remains neutral with regard to jurisdictional claims in published maps and institutional affiliations. 


\section{Affiliations}

Katie E. Commender ${ }^{1} \cdot$ John F. Munsell ${ }^{2} \cdot$ Adrian Ares $^{2} \cdot$ B. Jay Sullivan ${ }^{2}$. James L. Chamberlain ${ }^{3}$

$\bowtie$ John F. Munsell

jfmunsel@vt.edu

1 Appalachian Sustainable Development, Abingdon, VA, USA

2 Department of Forest Resources and Environmental Conservation, Virginia Tech, Blacksburg, VA, USA

3 USDA Forest Service, Southern Research Station, Blacksburg, VA, USA 